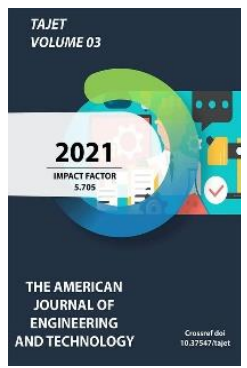

Copyright: Original content from this work may be used under the terms of the creative commons attributes 4.0 licence.

\title{
Requirements For The Formation Of The Historical Structure And Internal Environment Of Secondary Schools
}

\author{
S. A. Qodirova \\ Associate Professor, Tashkent Institute Of Architecture And Construction, Uzbekistan \\ N. A. Aripova \\ Associate Professor, Tashkent Institute Of Architecture And Construction, Uzbekistan \\ L. Sh. Raximov \\ Assistant, Tashkent Institute Of Architecture And Construction, Uzbekistan \\ J. O. Turebaev \\ Magistr, Tashkent Institute Of Architecture And Construction, Uzbekistan \\ U. X. Abdusalomov \\ Magistr, Tashkent Institute Of Architecture And Construction, Uzbekistan
}

\section{ABSTRACT}

The foundation of knowledge is the school threshold, the school is closely connected with the future. The motto of the President of the Republic of Uzbekistan "The threshold of a new Uzbekistan begins at school" is a unique initiative of the XXI century, which serves to make the future of the population and all young people a great and strong state. This initiative gives architects spiritual strength. This means that each building must be clearly visible to the public in terms of its appearance.

\section{KEYWORDS}

Orientation, functional zones, shops, plot, security strips, square, corridor, layout, style, building, fura truck, room, floor

\section{INTRODUCTION}

The speech of the President of the Republic of Uzbekistan Shavkat Mirziyoyev at the solemn ceremony dedicated to the "Day of Teachers and Coaches" on October 1, 2020 reads as follows: "The more educated our children are in school, the faster the high-tech sectors of the economy will develop and the more social problems will be solved. So, if I say that the threshold of a new Uzbekistan begins with school, I think all our people will support this idea."[1]. This is, of course, the most unique initiative for the development of our state. 
The President emphasized that every leader should be constantly aware of the state of schools in his area, especially in rural areas, in order to eliminate problems and shortcomings there.

The main type of general education schools in Uzbekistan are 11-year basic schools, in which children study in grades 1-11 from the age of 7 . The maximum capacity of a school should, as a rule, not exceed 36 classes (i.e., 4 streams consisting of 9 classes). It is recommended that the orientation of the main rooms of the schools take into account the southern and south-eastern orientation of the classrooms and cabinets, while the north orientation is preferred for the fine arts and drawing, computer science classrooms. Northern orientation can be applied to elementary classes and biology laboratories.

With the azimuth orientation of the windows at 75285 , sun protection should be provided to prevent overheating and restore proper thermal insulation to the surveyed areas. The choice of shading devices is determined by the project, taking into account local conditions. For the hot shops of the kitchens, the northern orientation is preferable. For low-rise buildings (single and double-storey), sun protection can be provided through landscaping measures (trees should be moved at a distance of not less than $10 \mathrm{~m}$ from the windows of the building).
Requirements for land plots. The location and size of land plots for schools and boarding schools were adopted in accordance with SNC 2.01.07. [2]

Land plots of schools and boarding schools are as follows: physical education and sports; learning experience; the main functional zones, such as recreation and economic zones, are required.

The area of green spaces of schools and boarding schools is $30-40 \%$ of the area, which includes green areas for recreation, physical education and experimental areas, as well as protective belts and green fences around the school grounds.

Such a specification of the work of secondary schools requires a well-organized spatial space, taking into account the characteristics of the age of students. In order to provide the best comfort conditions for the educational process, the volumetric and spatial structure of schools is based on the grouping of rooms into separate zones, which are identical in terms of functionality. [3]

According to the scheme, all classrooms of the school will be combined into four functional zones: 1.Vestibular zone, 2.I-V-class zone, 3.VI$\mathrm{XI}$ class zone, 4. General school rooms, including rooms for administrative and technical functions.

\section{THE MAIN FINDINGS AND RESULTS}




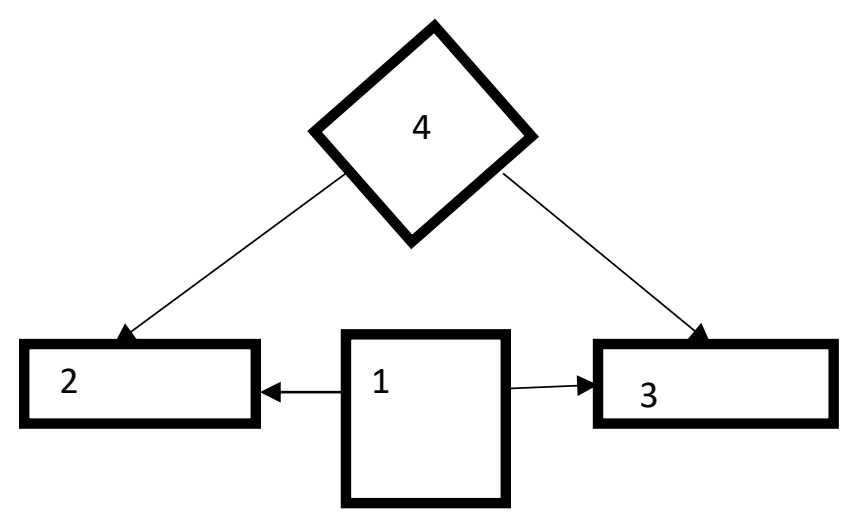

An example of the functional zoning of the historical structure of a secondary school

\section{Requirements for the school environment:}

Requirements for the educational process.

1. Equipping the classroom in accordance with the learning process: a board of a given size; study desks and chairs; cabinets for storage of methodical materials; special stands for displaying materials.

2. Place $30-40$ students in the classroom with the following options: explanation next to the board; conducting written work; conducting group lessons; organization of general class games (for primary school students).

3. Use of teaching aids: showing color slides, movies; television (television), ie teaching on television.

4. Necessary conditions for "extended day" training. To achieve this goal, the transformation of the classroom into the most diverse, providing individual group training.

\section{Hygienic requirements:}

1. Lighting comfort: the uniformity of illumination should not exceed 1: 5 ratio (allowable light contrasts); the proximity of the board; lack of dazzling light.

a) Which provides the optimal orientation of the classrooms on the sides of the light - east and north, west-facing insulation in one-shift training;

b) Sun protection;

c) Ventilation and artificial ventilation.

Physiological requirements are higher nervous activity and psychology:

a) a) Unlike all other rooms, the classroom must have its own "face". It should have a sufficiently bright (obvious) characteristic;

b) Concentration of attention. Eliminate all external negative interference factors (noise, walks in front of classrooms, 
unnecessary tables, writers, poets, etc.).[4]

Architects in a number of developed Western countries believe that it is advisable for a class to have a complex configuration, since an

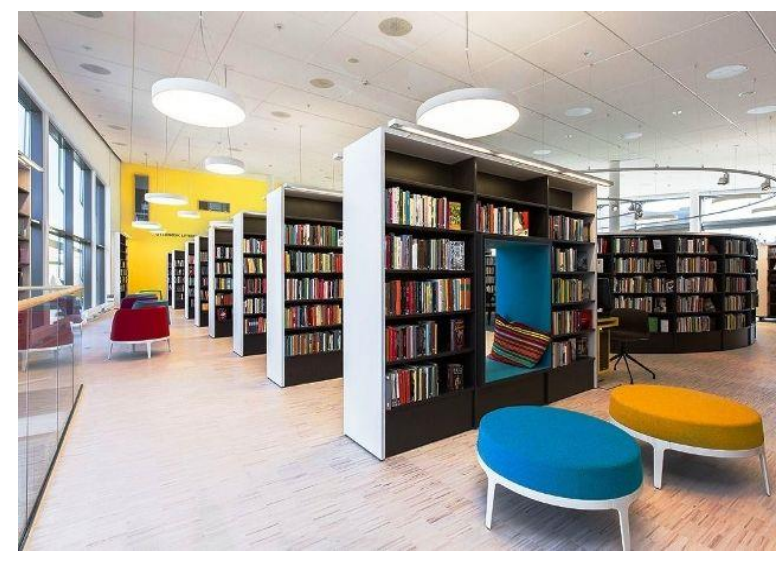

Figure -1

Create an environment that does not distract the reader. For this, the elements that make up the interior of the classroom must be brought together (integrity), and their number must be minimized.

In each educational institution, especially at school, breaks are provided for the purpose of eliminating (balancing) the mental exhaustion of the student and activating the functional interesting spatial latitude differs with a different configuration. The interior of the classroom is required to meet the requirements for concentration of students during the lessons.

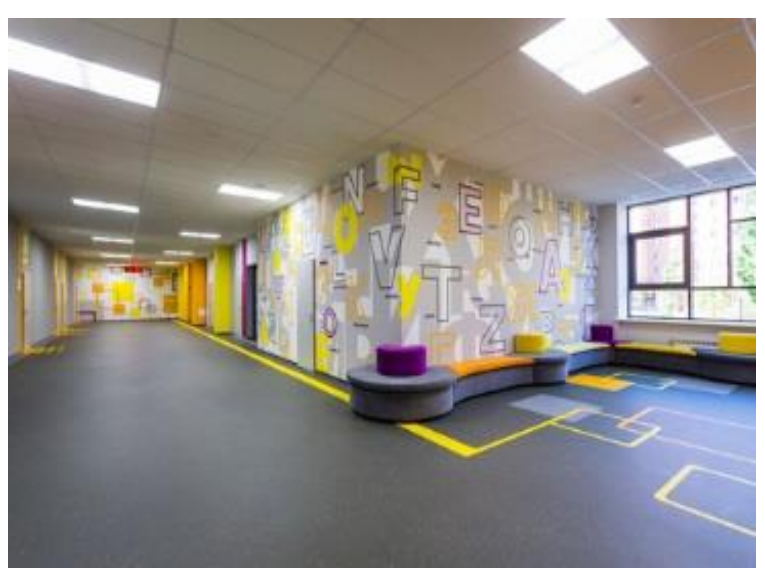

Figure -2

processes of his body. To do this, each section or training block will have spacious corridors and recreation areas in the form of a hall. In hot climates, recreation can be open or in the form of a gallery. For schools in Uzbekistan, the high temperature in the country and the hot season will be of great importance in mitigating the detrimental effect of this factor on the body of schoolchildren. 


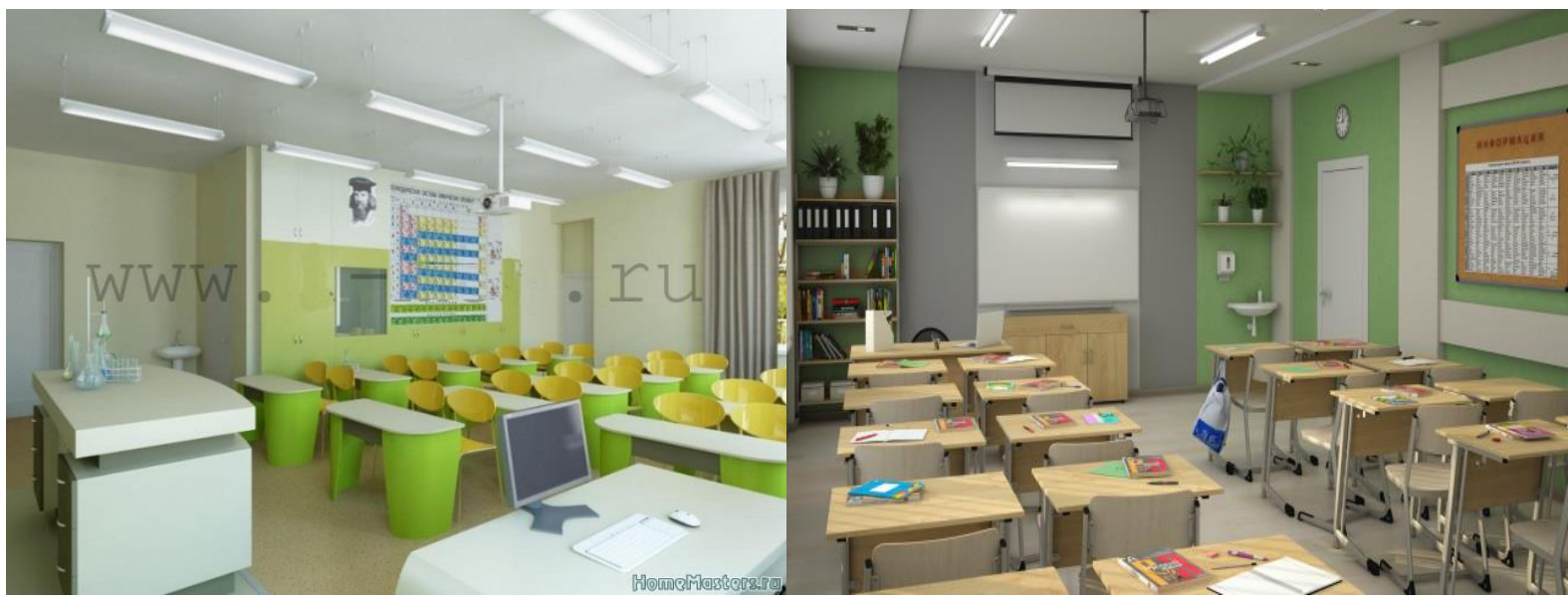

Figure-3

Figure -4

\section{CONCLUSION}

It is well known that the motto of the President of the Republic of Uzbekistan Sh.M.Mirziyoev "The threshold of a new Uzbekistan begins with school" is now the most unique initiative for the development of our state. The school project is proposed because it showed a long way to the creativity of the population and youth. The main goal is to radically reform the educational process at school. [5]

\section{REFERENCES}

1. Sh.M.Mirziyoev. New Uzbekistan newspaper. 2020y. №188.

2. SHNK 2.01.07-09 "Public buildings and structures".

3. Qodirova S.A. "Interior and equipment" Textbook. 2020y. TAQI.

4. Ubaydullaev X.M., Inogamova M.M. "Typological bases of design of residential and public buildings" (textbook) T. "Heir" 2009.

5. https://otzovik.com/review_1234272.ht $\mathrm{ml}$ 